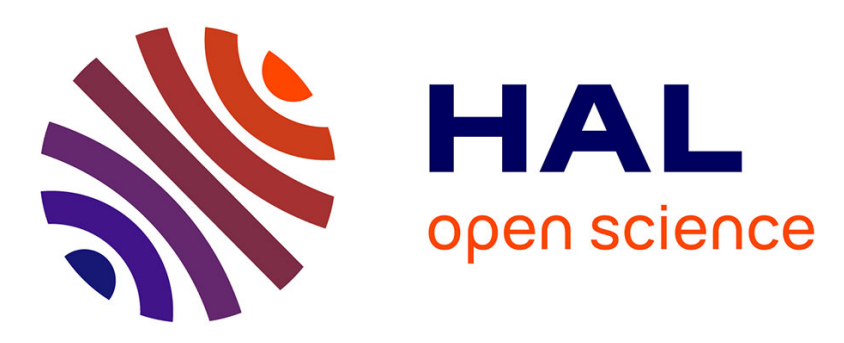

\title{
Theophylline as an adjunct to control malignant ventricular arrhythmia associated with early repolarization
}

Tilman Perrin, Régis Guieu, Linda Koutbi, Frédéric Franceschi, Jérôme Hourdain, Michele Brignole, Jean-Claude Deharo

\section{To cite this version:}

Tilman Perrin, Régis Guieu, Linda Koutbi, Frédéric Franceschi, Jérôme Hourdain, et al.. Theophylline as an adjunct to control malignant ventricular arrhythmia associated with early repolarization. PACE - Pacing and Clinical Electrophysiology, 2017, 41 (5), pp.444-446. 10.1111/pace.13240 . hal-01760765

\section{HAL Id: hal-01760765 \\ https://hal.science/hal-01760765}

Submitted on 25 May 2018

HAL is a multi-disciplinary open access archive for the deposit and dissemination of scientific research documents, whether they are published or not. The documents may come from teaching and research institutions in France or abroad, or from public or private research centers.
L'archive ouverte pluridisciplinaire HAL, est destinée au dépôt et à la diffusion de documents scientifiques de niveau recherche, publiés ou non, émanant des établissements d'enseignement et de recherche français ou étrangers, des laboratoires publics ou privés. 


\title{
Theophylline as an adjunct to control malignant ventricular arrhythmia associated with early repolarization
}

Tilman Perrin MD, Regis Guieu MD, Linda Koutbi MD, Frédéric Franceschi MD, Jérôme Hourdain MD, Michele Brignole MD, Jean-Claude Deharo MD

\begin{abstract}
Early repolarization (ER) has been associated with an increased risk of sudden cardiac arrest. Interestingly, ventricular arrhythmias seem to be triggered by parasympathetic stimulation. In the present case report, we describe complete control of highly frequent malignant ventricular arrhythmias after adding theophylline to ineffective oral hydroquinidine and high-rate pacing in a patient suffering from malignant ER. We hypothesize that the theophylline-mediated enhanced beta-adrenergic stimulation could reduce the transmural myocardial voltage discrepancy by increasing the inward $I_{C a, L}$ current.
\end{abstract}

\section{INTRODUCTION}

Early repolarization (ER), particularly with J-point elevation in the inferior leads and a notching ER pattern, has been associated with a twofold-increased risk of sudden cardiac arrest. $\underline{1}$

\section{CASE REPORT}

The case of a 12-year-old boy with inferior ER, for whom hypervagotonia played a key role in triggering malignant ventricular arrhythmias, has been previously reported. $\underline{2}$ Despite complete disappearance of the ER pattern with hydroquinidine therapy $(300 \mathrm{mg}$ thrice daily), $\underline{2}$ the teenager still suffered recurrent life-threatening ventricular arrhythmia episodes, and thus received an implantable cardioverter defibrillator (ICD) after resuscitation from cardiac arrest. During the following months, the patient received frequent ICD shocks for nocturnal polymorphic ventricular tachycardia. Due to recurrent arrhythmias in spite of three premature ventricular contraction ablation procedures in tertiary reference centers, hydroquinidine was replaced by disopyramide. Nevertheless, since the arrhythmias continued to occur at night, always preceded by sinus bradycardia, it was decided to pace the patient nocturnally at 95 beats/min (lower rate interval set at 95 beats/min, night rate set at 60 beats/min from 8:30 a.m. to 8:30 p.m.). Given that appropriate ICD therapies and electrical storms were still triggered by hypervagotonia during sleep, theophylline was initiated at $500 \mathrm{mg}$ twice daily for a target plasma concentration of $20 \mu \mathrm{g} / \mathrm{mL}$, in association with hydroquinidine (100 mg thrice daily). On follow-up $>2$ years, no other therapy was required for this patient who, prior to theophylline initiation, experienced 1.9 ventricular arrhythmia episodes per month on average, with no ICD shock-free period exceeding 4 months (Figure 1 ). Of note is that one inadequate ICD shock was recorded, owing to rapidly conducted atrial fibrillation on a basketball game.

\section{DISCUSSION}

In similitude with the Brugada syndrome, the ER syndrome pathology relies on a transmural myocardial voltage discrepancy due to larger $I_{\text {to }}$ and $I_{K \text {-ATP }}$ outflow potassium currents, along with reduced $\mathrm{I}_{\mathrm{Ca}, \mathrm{L}}$ and $\mathrm{I}_{\mathrm{Na}}$ inflow currents in the epicardium rather than endocardium, 
thereby favoring local Phase 2 reentry and malignant ventricular arrhythmias. $\underline{3}-\underline{5}$ Importantly, it has been shown that amplitudes of J-waves increase during bradycardia or increased vagal tone, $\underline{6}-\underline{8}$ especially before arrhythmia, $\underline{7}$ and that VF episodes are commonly triggered by short-long-short sequences (Figure 2). $\underline{9}$ Conversely, shortening the RR interval by pacing does attenuate the J-wave, due to slower $I_{\text {to }}$ current recovery at shorter cycle lengths. $3, \underline{4}$ Several pharmacological approaches to reduce ventricular arrhythmia have also been investigated over the years. Hydroquinidine counteracts the marked action potential abbreviation in epicardial cells, on account of its $I_{\text {to }}$-channel blocking and anticholinergic properties, thus normalizing electrocardiograms in patients with ER. $\underline{4}$ 10 Beta-adrenergic stimulation with isoproterenol was demonstrated to successfully control VT storms in patients with $E R$, increasing the inward $I_{C a, L}$ current and reducing the outward $I_{\text {to }}$ current, thus restoring the action potential dome in the epicardium. $\underline{4}, 11$ More recently, due to the same transmembrane current changes, the oral phosphodiesterase type III inhibitor cilostazol has been shown to successfully control recurrent VF episodes in patients with Brugada and ER syndromes. $\underline{3}, \underline{12}, \underline{13}$ We propose another approach for long-term management of malignant ER syndrome, based on the adenosine signaling pathway. This purine nucleoside exerts negative chronotropic and dromotropic effects on the sinoatrial node, atria, and atrioventricular node via A1 adenosine receptor (AR)-mediated (1) direct activation of the hyperpolarizing inward $I_{K, A c h}$ current, along with (2) antiadrenergic indirect inactivation of the inward rectifying potassium current $\left(\mathrm{I}_{\mathrm{K}}\right)$, inward calcium current $\left(\mathrm{I}_{\mathrm{Ca}, \mathrm{L}}\right)$, and "funny» hyperpolarization-activated inward natrium current $\left(I_{f}\right) .14$ Owing to less $I_{K, A c h}$ expression in ventricular myocytes, adenosine has no relevant direct effect on the action potential duration in human ventricles but has been shown to indirectly attenuate the catecholamine-stimulated inward $I_{C a, L}$ current.14 Theophylline, a nonselective A1-AR antagonist, increases the baseline heart rate and enhances the release of catecholamines from the sympathoadrenal system, $\underline{15}$ being effective for treatment of patients with recurrent unexplained syncope potentially mediated by adenosine.16 We hereby report another potential indication for its use. We hypothesize that theophylline could reduce the transmural myocardial voltage discrepancy in our patient by increasing the inward $I_{\mathrm{Ca}, \mathrm{L}}$ current via the enhanced beta-adrenergic stimulation, thereby counteracting the electrophysiologic corollaries of increased vagal tone and decreased sympathetic tone occurring at night. On the other hand, we do not expect that the positive chronotropic effect of theophylline plays a major role in our case, as rapid ventricular pacing was insufficient to prevent occurrence of ventricular arrhythmia. On the down side, our patient received an inappropriate ICD shock because of rapid atrial fibrillation resulting from the xanthines-mediated adrenergic stimulation and accelerated atrioventricular conduction. 14 Fortunately, we noticed no recurrence since the upgrade for a dual-chamber ICD system at box-change for battery depletion.

\section{CONCLUSION}

To the best of our knowledge, we report the first case of a successful control of recurrent ventricular arrhythmias in the setting of a malignant ER syndrome by adding theophylline to prior ineffective oral hydroquinidine and high-rate pacing. We hereby present a promising adjuvant oral treatment regimen based on the vago-sympathetic homeostasis, which deserves further investigations in larger case series.

1-Cheng YJ, Lin XX, Ji CC, et al. Role of early repolarization pattern in increasing risk of death. J Am Heart Assoc. 2016;5:1-11. 
2-Koutbi L, Roussel M, Haissaguerre $M$, Deharo JC. Hyperpnea test triggering malignant ventricular arrhythmia in a child with early repolarization. Heart Rhythm. 2012;9:1153-1156.

3-Antzelevitch C, Yan GX, Ackerman MJ, et al. J-Wave syndromes expert consensus conference report: emerging concepts and gaps in knowledge. Europace. 2017;19:665-694.

4-Mercer BN, Begg GA, Page SP, Bennett CP, Tayebjee MH, Mahida S. Early repolarization syndrome; mechanistic theories and clinical correlates. Front Physiol. 2016;7:266.

5-Shu J, Zhu T, Yang L, Cui C, Yan GX. ST-segment elevation in the early repolarization syndrome, idiopathic ventricular fibrillation, and the Brugada syndrome: cellular and clinical linkage. J Electrocardiol. 2005;38:26-32.

6-Koncz I, Gurabi Z, Patocskai B, et al. Mechanisms underlying the development of the electrocardiographic and arrhythmic manifestations of early repolarization syndrome. $J \mathrm{Mol}$ Cell Cardiol. 2014;68:20-28.

7-Mizumaki K, Nishida K, Iwamoto J, et al. Vagal activity modulates spontaneous augmentation of $\mathrm{J}$-wave elevation in patients with idiopathic ventricular fibrillation. Heart Rhythm. 2012;9:249-255.

8-Kasanuki $\mathrm{H}$, Ohnishi S, Ohtuka M, et al. Idiopathic ventricular fibrillation induced with vagal activity in patients without obvious heart disease. Circulation. 1997;95:2277-2285.

9-Nam GB, Ko KH, Kim J, et al. Mode of onset of ventricular fibrillation in patients with early repolarization pattern vs. Brugada syndrome. Eur Heart J. 2010;31:330-339.

10-Haissaguerre M, Sacher F, Nogami A, et al. Characteristics of recurrent ventricular fibrillation associated with inferolateral early repolarization role of drug therapy. J Am Coll Cardiol. 2009;53:612-619.

11-Maury $P$, Hocini $M$, Haissaguerre $M$. Electrical storms in Brugada syndrome: review of pharmacologic and ablative therapeutic options. Indian Pacing Electrophysiol J. 2005;5:2534.

12-Tsuchiya T, Ashikaga K, Honda T, Arita M. Prevention of ventricular fibrillation by cilostazol, an oral phosphodiesterase inhibitor, in a patient with Brugada syndrome. J Cardiovasc Electrophysiol. 2002;13:698-701.

13-Iguchi K, Noda T, Kamakura S, Shimizu W. Beneficial effects of cilostazol in a patient with recurrent ventricular fibrillation associated with early repolarization syndrome. Heart Rhythm. 2013;10:604-606.

14-Belardinelli L, Shryock JC, Song Y, Wang D, Srinivas $M$. Ionic basis of the electrophysiological actions of adenosine on cardiomyocytes. FASEB J. 1995;9:359-365.

15-Vestal RE, Eiriksson CE, Jr, Musser B, Ozaki LK, Halter JB. Effect of intravenous aminophylline on plasma levels of catecholamines and related cardiovascular and metabolic responses in man. Circulation. 1983;67:162-171. 
16-Brignole M, Solari D, lori M, Bottoni N, Guieu R, Deharo JC. Efficacy of theophylline in patients affected by low adenosine syncope. Heart Rhythm. 2016;13:1151-1154. 


\section{Figure 1}

Home monitoring diagram of our patient. The extended follow-up demonstrates the successful rhythm control by adding theophylline to hydroquinidine

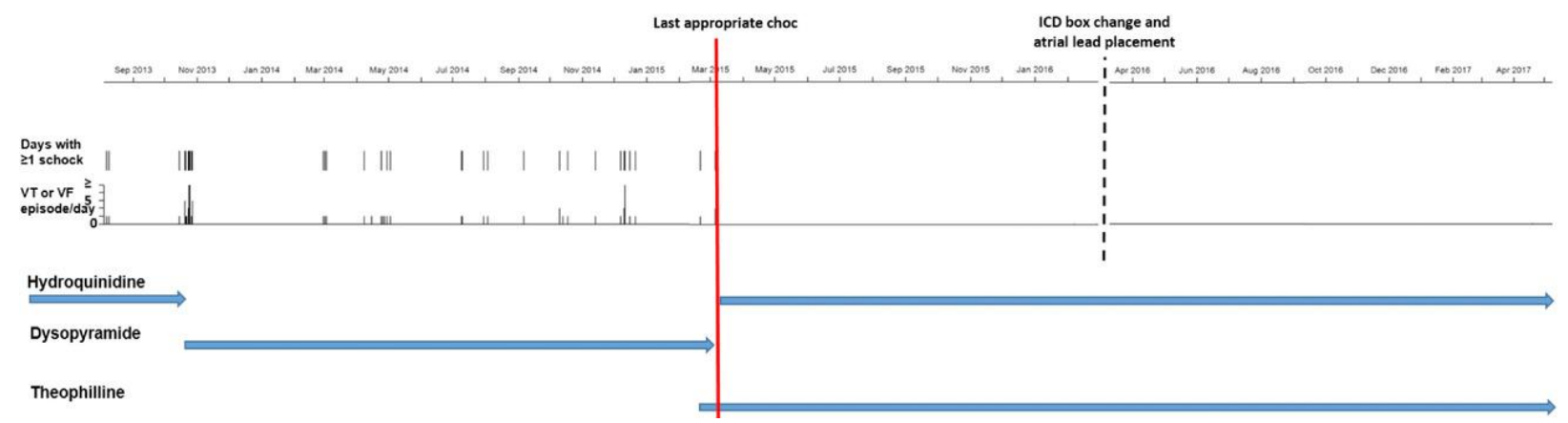

\section{Figure 2}

Initiation of ventricular fibrillation. Electrocardiogram monitoring strip of our patient showing a short-long-short sequence that led to an increase in amplitude of the inferior early repolarization pattern and triggered a ventricular arrhythmia

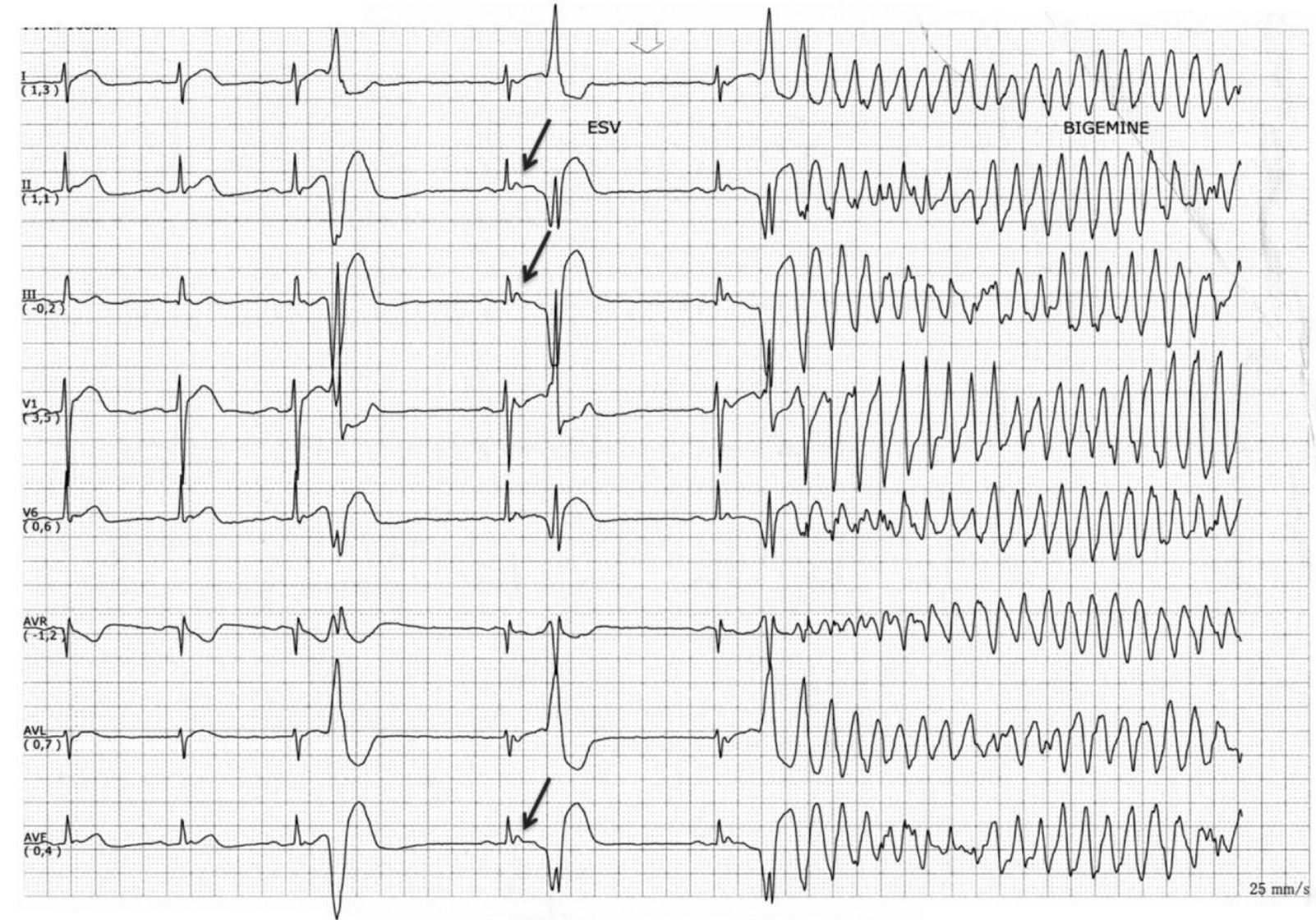

